\title{
Evaluation of aquifer protective capacity of overburden unit and soil corrosivity in Makurdi, Benue state, Nigeria, using electrical resistivity method
}

\author{
Daniel N Obiora*, Adeolu E Ajala and Johnson C Ibuot \\ Department of Physics and Astronomy, University of Nigeria, Nsukka, Nigeria. \\ *Corresponding author.e-mail: daniel.obiora@unn.edu.ng
}

\begin{abstract}
This paper presents result of 30 vertical electrical soundings carried out in Makurdi, Benue state capital, north-central Nigeria to evaluate aquifer protective capacity and soil corrosivity of overburden units in the study area. This was done using the Schlumberger electrode array to obtain the data and was modelled using computer iteration (Winresist software). The field data gives a resolution with 3-4 geoelectric layers and the observed frequencies in curve types include: $30 \%$ of $\mathrm{KQ}, 16.67 \%$ of $\mathrm{QH}, 6.67 \%$ of $\mathrm{AA}$ and $\mathrm{K}, 3.33 \%$ of $\mathrm{HA}, \mathrm{Q}$ and $\mathrm{A}, 10 \%$ of $\mathrm{H}, \mathrm{KH}$ and $\mathrm{HK}$. Using the longitudinal unit conductance $(\mathrm{S})$, the protective capacities of the study area were classified as $36.67 \%$ weak, $10 \%$ poor, $40 \%$ moderate, and $13.33 \%$ as good. The corrosivity ratings of the study area show that $10 \%$ is strongly corrosive, $23 \%$ moderately corrosive, $37 \%$ slightly corrosive, and $30 \%$ noncorrosive The results reasonably provide information on areas where industries can be sited and iron pipes can be laid in order to safeguard the hydrological setting for resident's safety in the study area. Regions with moderate/good protective capacity are good sites for locating boreholes.
\end{abstract}

\section{Introduction}

The role of water cannot be over-emphasized as it plays a very important role in the existence of life (plant and animal). Groundwater is that water found within the saturated voids beneath the ground. The source of groundwater is chiefly from precipitating atmospheric moisture, which has percolated down into the soil and subsoil layers. It is available only when the rocks in the zone of saturation are permeable enough to transmit sufficient quantity of water to wells, springs or streams. Groundwater is the subsurface water which fully saturates the pores and behaves in response to gravitational force (Strahler 1973). The availability, quantity and exploitability of groundwater depend on the porosity and permeability of the host rocks. Both play important roles in groundwater movement and recovery. The porosity of a geologic material is the amount of water (fluid) the material can hold. It is the volume ratio of the pore spaces to the total volume of soil, rock or sediment (Chernicoff and Whitney 2009).

However, the present social demands are not only to detect new groundwater resources but to protect them. The potability of groundwater can be contaminated by leachate from dumpsites, salt intrusion, oil spillage, mining activities, sewage (from latrines, underlined petroleum pipes and septic tanks) (Makeig 1982). Dumpsites and latrines are sited without considering the hydrogeological settings of the area, thereby rendering the future of groundwater at risk (Ugbaja and Edet 2004). The widespread use of chemical products, coupled with the disposal of large volumes of waste materials, poses the potential for widely distributed

Keywords. Aquifer; corrosivity; longitudinal conductance; vertical electrical sounding; Makurdi; geoelectric layers. 
groundwater contamination. Hazardous chemicals, such as pesticides, herbicides, and solvents, are used ubiquitously in everyday life. These and a host of other chemicals are in widespread use in urban, industrial, and agricultural settings. Whether intentionally disposed of, accidentally spilled, or applied to the ground for agricultural reasons, some of these chemicals can eventually reach the groundwater and contaminate it. Because of the volumes of toxic wastes and because of their stability in groundwater, such contamination can pose a serious threat to public health. Almost every major

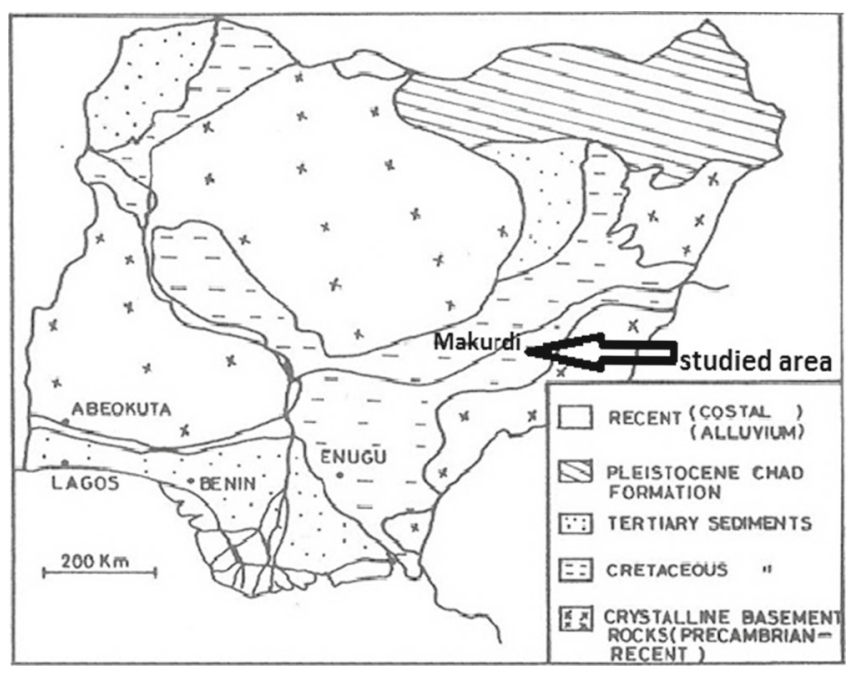

Figure 1. Geological map of Nigeria (Kogbe 1989). industrial and agricultural site has in the past disposed of its wastes on site, often in an inconspicuous location on the property. Every municipality has had to dispose of its waste at selected locations within its proximity. Past waste-disposal practices and dealing with spills have not always been considered as potential for groundwater contamination.

The rate of groundwater contamination depends on permeability, porosity, and overburden thickness of geologic formations. When the underlying geologic material is unconsolidated and uncompacted, such as coarse sand, the polluting influents are capable of escaping into the subsurface to contaminate groundwater, rendering the soil corrosive and forming a polluting plume that extends hundreds of meters (Keswick et al. 1982). Using electrical resistivity method and borehole lithologic logs, Dan-Hassan (2001) found out that the aquifers of the basement complex rocks of north-central Nigeria are predominantly weathered overburden aquifers. There is always a chance that pipelines could leak or rupture and a pipeline failure can constitute serious hazards to the environment, assets, and even humans due to explosion and leakage (Yahaya et al. 2009). Using geophysical studies, environment can be evaluated without interfering with the hydrogeologic system (Mogaji et al. 2007). Abiola et al. (2009) studied the groundwater potential and aquifer protective capacity of overburden units in Ado Ekiti and delineated

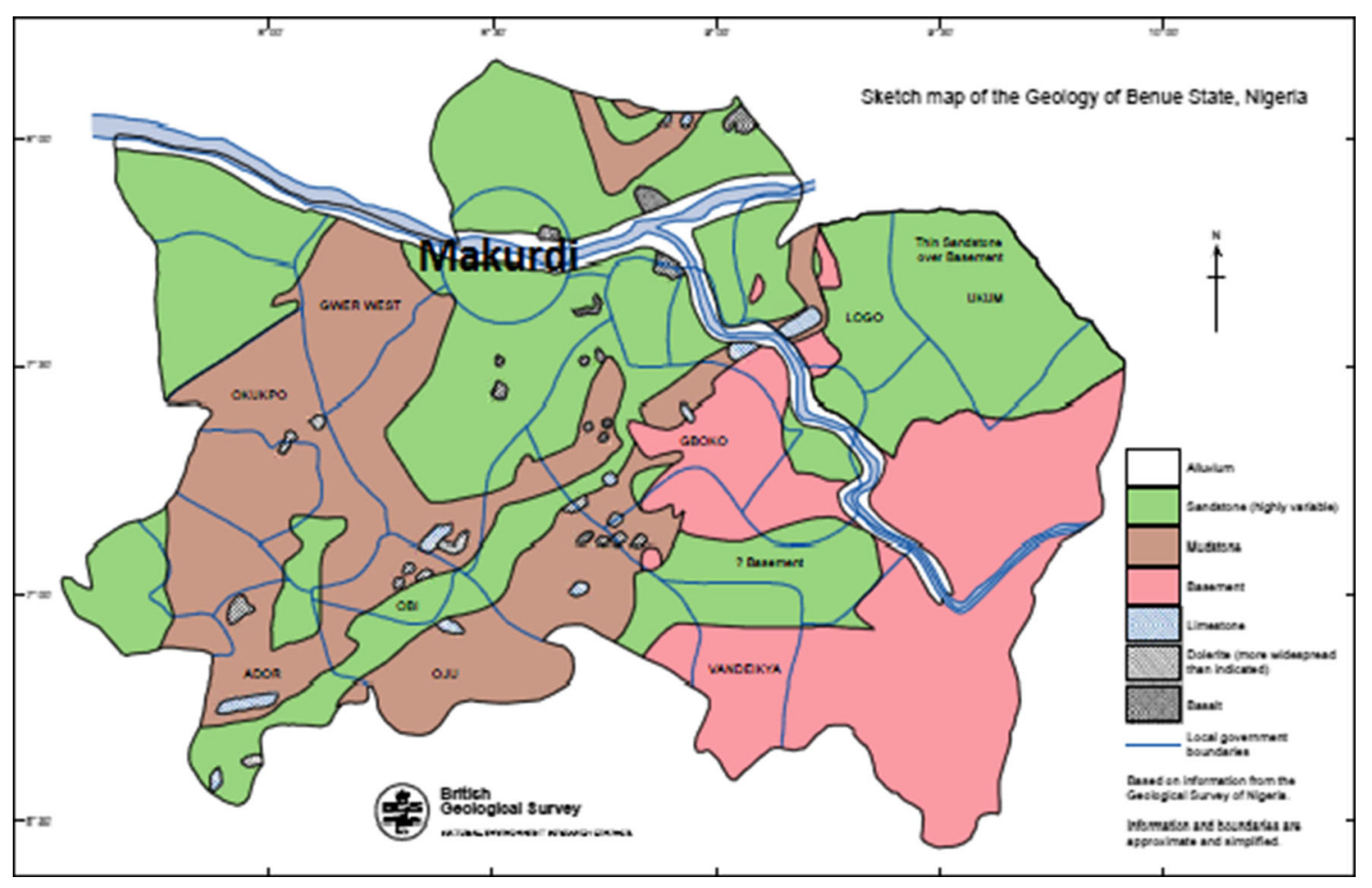

Figure 2. Geological map of Benue State (British Geological Survey 2001). 
three groundwater potential zones (high, medium, and low) and aquifer protective capacity (good, moderate, weak, and poor) in the study area. Some recent researchers had employed electrical resistivity method in investigating aquifer protective capacity and soil corrosivity in Nigeria (Adeniji et al. 2014; George et al. 2014). The use of geophysics for both groundwater resource mapping and for water quality evaluations has increased dramatically due to the rapid advances in microprocessors and associated numerical modelling solutions. The vertical electrical sounding (VES) has proved very popular with groundwater studies due to the simplicity of the technique. Traditional methods for characterizing protective layers include test hole drilling and analysis of log, with the objective being to characterize thickness and/or lateral extent of the protective layer. Disadvantages of such investigations are that they can be labour-intensive and expensive (Kalinski et al. 1993).

Today, we are witnessing an increasing number of boreholes drilled by government, nongovernmental organizations, and individuals. This shows clearly that groundwater is effectively complementing other sources of water supply in the area. This is due to the rate of contamination of surface water through the effect of inordinate quest for development. Surface water is found to be grossly degraded in quality because of its physical, biological, or chemical contaminants (Edet and Worden 2009). Design of appropriate groundwater management strategies in any geologic environment

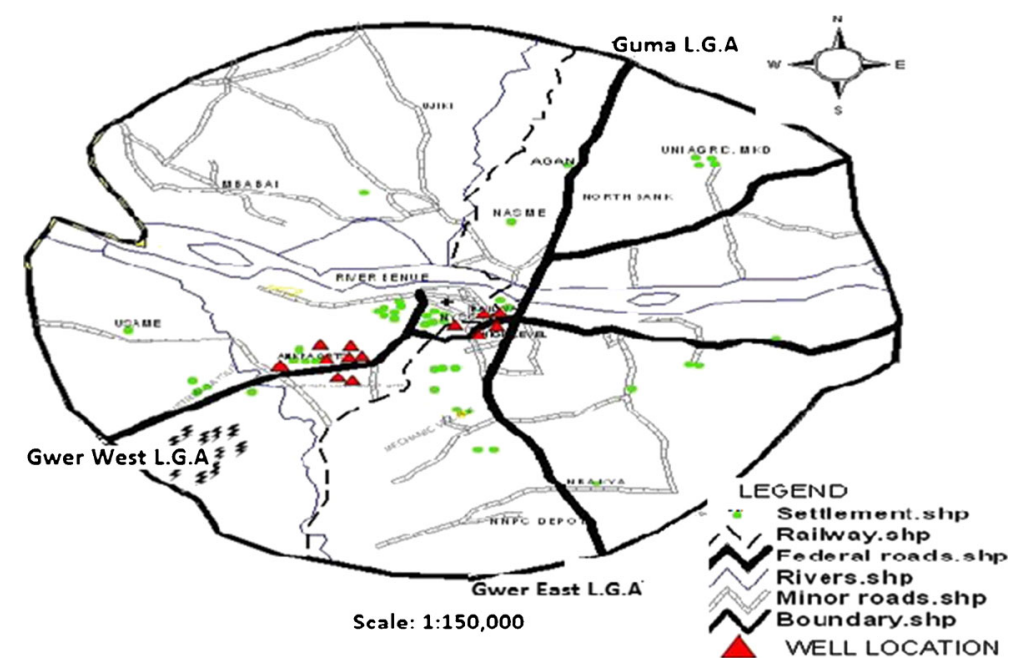

Figure 3. Sketch map of Makurdi showing the road network and drainage pattern (Amadi et al. 2010).

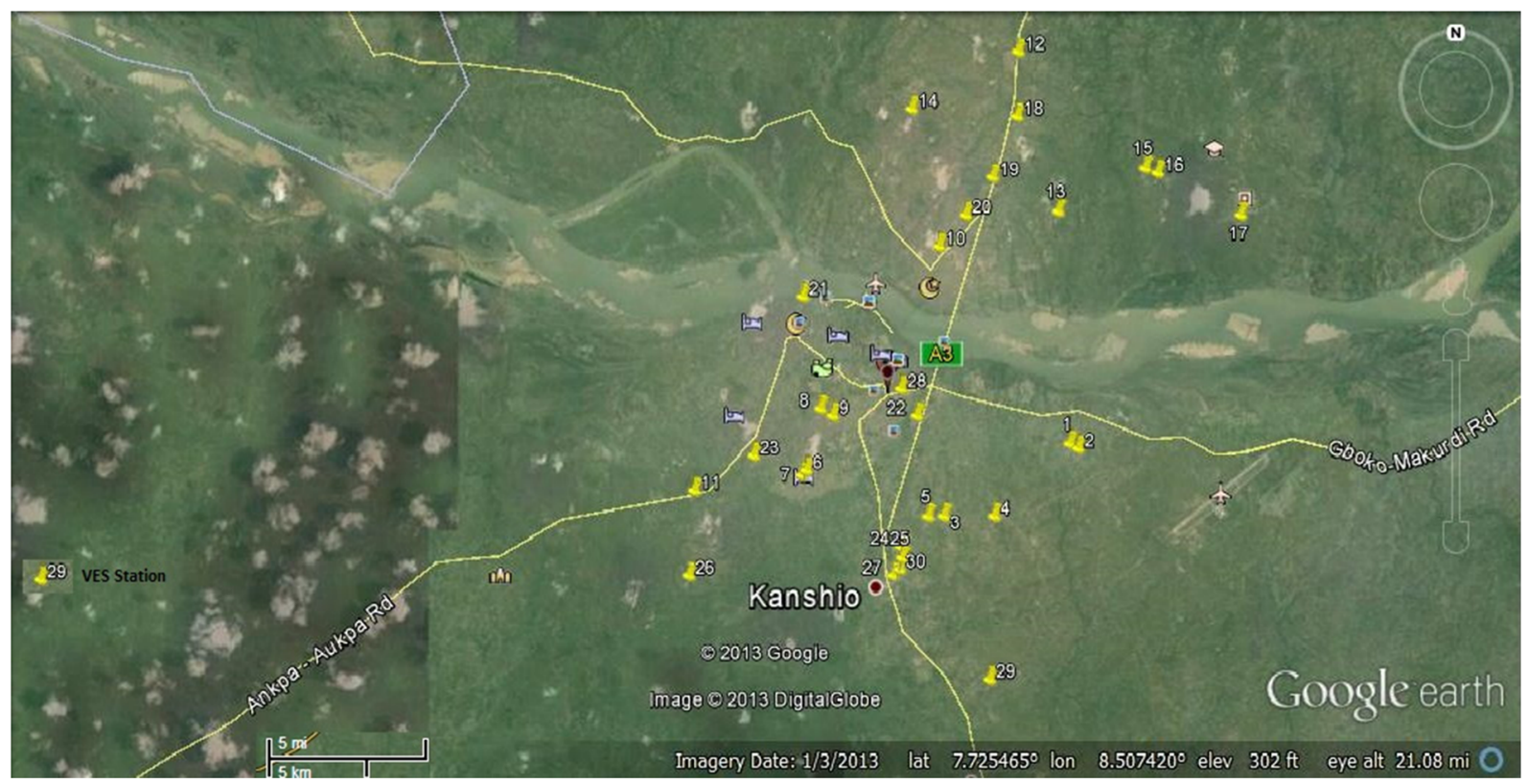

Figure 4. Google Earth map showing VES stations. 

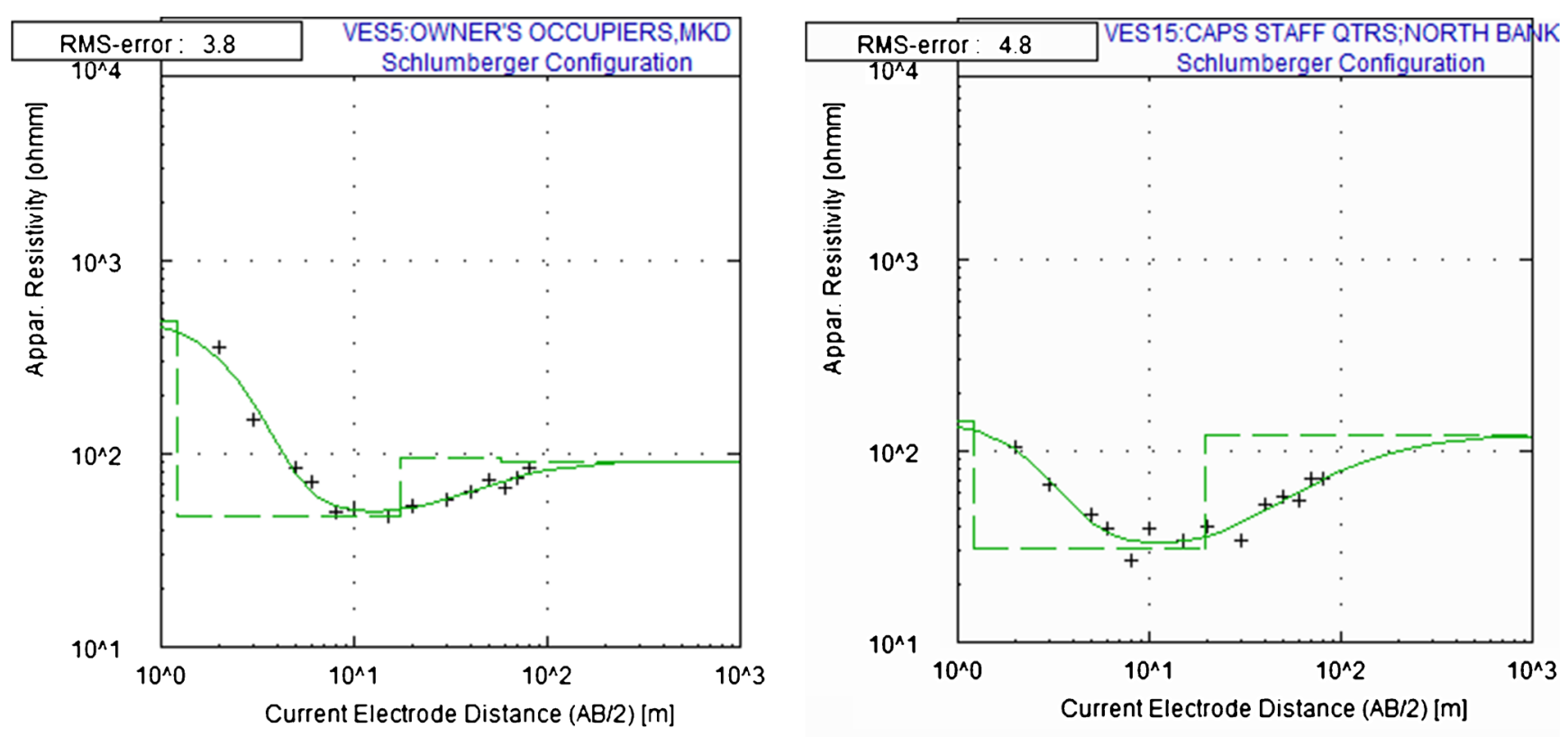

\begin{tabular}{|cccc|}
\hline No & Res & Thick & Depth \\
\hline 1 & 490.2 & 1.2 & 1.2 \\
2 & 47.3 & 16.1 & 17.3 \\
3 & 95.1 & 40.1 & 57.4 \\
4 & 91.7 & $-y^{--}$ & - \\
\hline
\end{tabular}

Figure 5. VES 5 geoelectric curve.

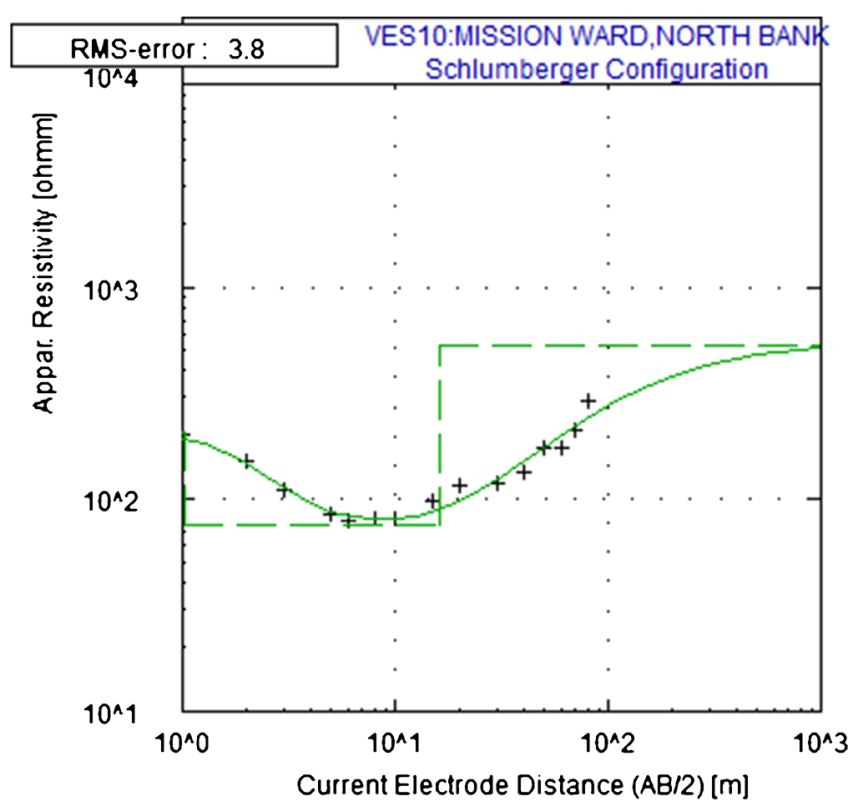

\begin{tabular}{|cccc|}
\hline No & Res & Thick & Depth \\
\hline 1 & 207.2 & 1.0 & 1.0 \\
2 & 75.4 & 15.3 & 16.3 \\
3 & 520.4 & $-\because$ & -- \\
\hline
\end{tabular}
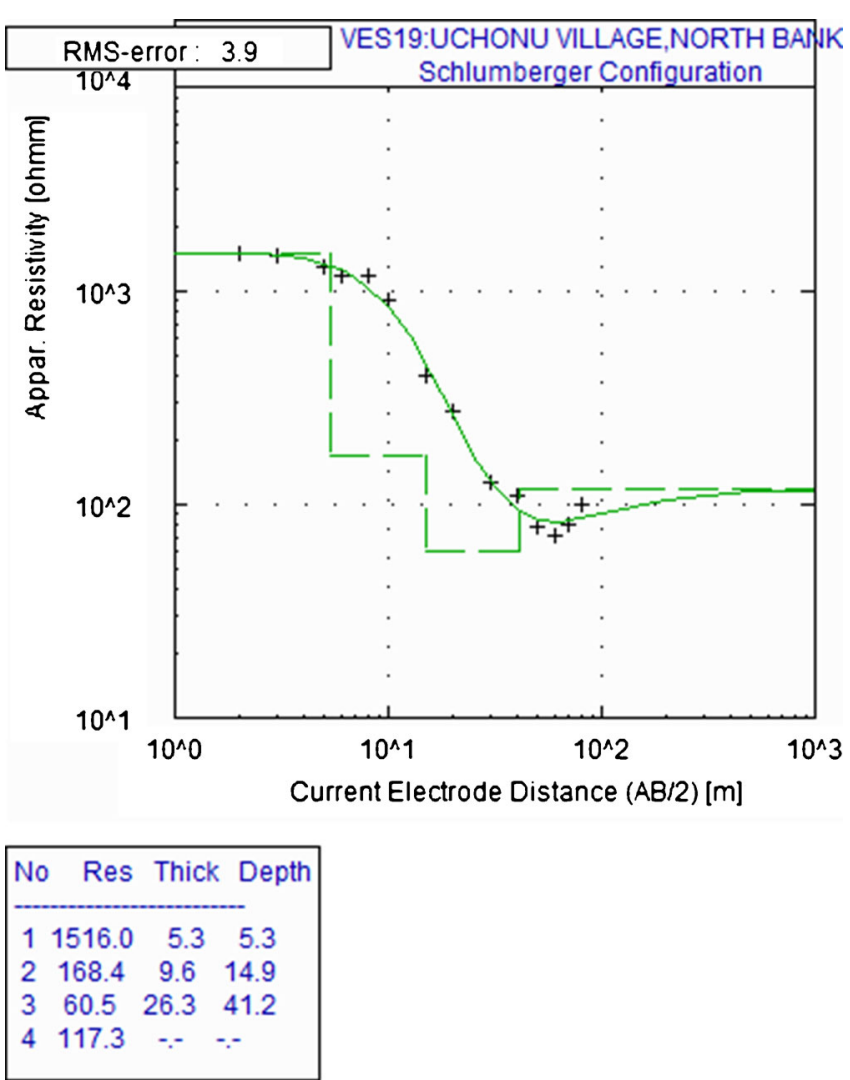


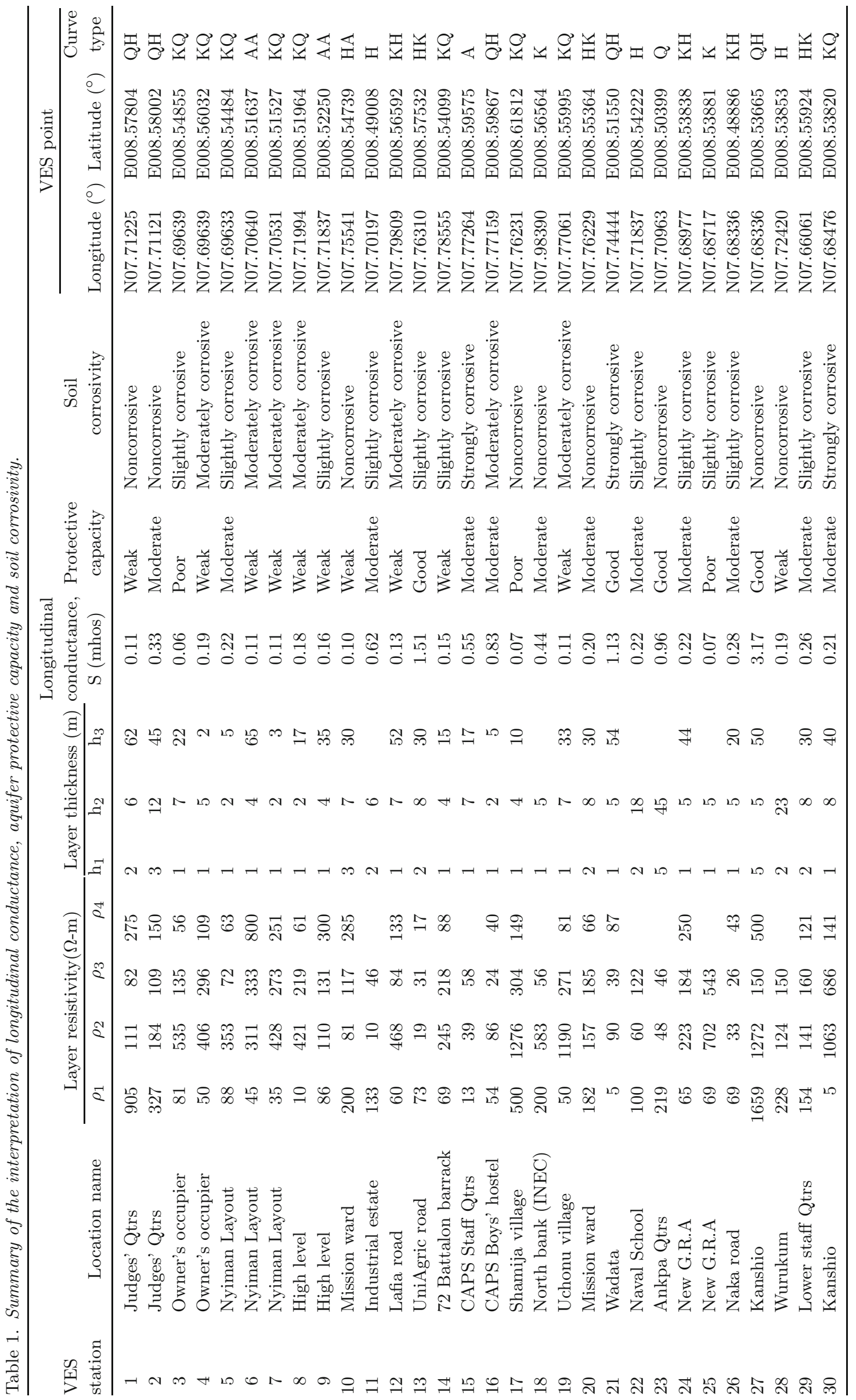


depends to a reasonable extent on the nature of subsurface materials, whose properties (physical and chemical) and spatial distribution constitutes the goal of all hydrogeological and hydrogeophysical investigations (George et al. 2014). Omoyoloye et al. (2008) defined overburden protective capacity as the ratio of the overburden thickness to its resistivity. The higher the overburden longitudinal conductance, the higher its protective capacity.

Schlumberger resistivity soundings have been used in this study to evaluate the aquifer protective capacity, longitudinal conductance, and corrosivity of overburden units in the study area. The result of this study will help identify areas where groundwater is or could be contaminated by leachates.

\section{Physiographic, geological and hydrogeological settings of the study area}

The study area is Makurdi, the Benue State capital, north-central, Nigeria (figure 1). Makurdi is known for its agricultural activities. It lies between latitudes $7^{\circ} 40^{\prime}$ and $7^{\circ} 50^{\prime} \mathrm{N}$ of the Equator and between longitude $8^{\circ} 20^{\prime}$ and $8^{\circ} 40^{\prime} \mathrm{E}$ of the Greenwich Meridian, covering a total area of about $670 \mathrm{~km}^{2}$ (figure 2). Makurdi lies within the Guinea savannah vegetation zone with a few patches of forests. The annual rainfall ranges between 1500 and $2000 \mathrm{~mm}$ with its peak rainfall in the months of July and September. Temperatures in March and April are about $38^{\circ} \mathrm{C}$ and $48^{\circ} \mathrm{C}$, respectively, while in December/January, the temperature is $27^{\circ} \mathrm{C}$ (Benue State Water Supply and Sanitation Agency 2008). The area is accessible through Nassarawa, Taraba, Obudu, Enugu, and Ankpa road. Also, a good road network exists within Makurdi metropolis and a railway line runs through the town from Enugu to Jos and Kaduna. The area can also be accessible through the Benue River which flows through from the Cameroon Mountain to the Niger-Benue confluence at Lokoja. Makurdi, the Benue State capital falls in the Makurdi Formation (figure 3). The formation overlies the Albian Shale. It consists of thick current bedded coarse grained deposits. The Makurdi sandstone has a thickness of about $900 \mathrm{~m}$ (Offodile 1976). The southern part of the Benue valley is generally gently undulating and punctuated by a few low hills. But towards the northeast, the relief is exaggerated by hills like the Lammuder and Ligri hills, which rise up to $600 \mathrm{~m}$ above sea level. The drainage consists of rivers which meander into the River Benue from the north and south directions.

Geologically, the Benue valley consists of a linear stretch of sedimentary basin running from about the present confluence of the Niger and the Benue rivers to the northeast, and is bounded roughly by the Basement Complex areas in the north and south of the river Benue. The elongated trough-like basin is continuous with the coastal basin, and in fact, has been correctly described as the longest arm of the Nigerian coastal basin (Offodile 2002).

\section{Data acquisition and interpretation}

The electrical resistivity survey involved VES, which is based on measuring the potentials between one electrode pair while transmitting direct current (dc) between another electrode pair. The depth of penetration is proportional to the separation between the electrodes in homogeneous ground, and varying the electrodes separation provides information about the stratification of the ground (Dahlin 2001). This method can be used in groundwater to determine depth, thickness, and boundary of an aquifer (Zohdy 1969). In this study, the Schlumberger array was performed using the vertical electrical sounding field procedure to assess the electrical resistivity of the subsurface and the thickness of the aquifer. The apparent resistivity $(\rho \alpha)$ was calculated using (Ibuot et al. 2013):

$$
\rho_{a}=\pi \cdot\left[\frac{(A B / 2)^{2}-(M N / 2)^{2}}{M N}\right] \cdot R_{a}
$$

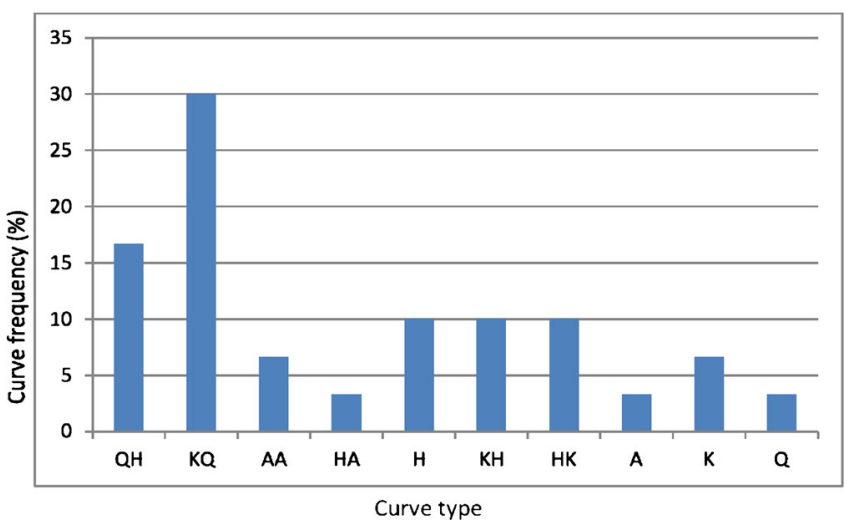

Figure 9. Bar chart showing frequency of curve type distribution in the study area.

Table 2. Modified longitudinal conductance/protective capacity rating (Henriet 1976; Oladapo et al. 2004).

\begin{tabular}{ll}
\hline $\begin{array}{l}\text { Longitudinal } \\
\text { conductance (mhos) }\end{array}$ & $\begin{array}{c}\text { Protective } \\
\text { capacity rating }\end{array}$ \\
\hline$>10$ & Excellent \\
$5-10$ & Very good \\
$0.7-4.9$ & Good \\
$0.2-0.69$ & Moderate \\
$0.1-0.19$ & Weak \\
$<0.1$ & Poor \\
\hline
\end{tabular}


where $A B$ is the distance between the two current electrodes, $M N$ is the distance between the potential electrodes, and $R_{a}$ is the apparent electrical resistance measured from the equipment. The equation can be simplified to (Ibuot et al. 2013)

$$
\rho_{a}=K \cdot R_{a}
$$

where the geometric factor

$$
K=\pi\left[\frac{(A B / 2)^{2}-(M N / 2)^{2}}{M N}\right] .
$$

Thirty vertical electrical soundings (VES) were carried out in the study area (figure 4). PZ-02 resistivity meter was used with maximum current electrodes spacing $(A B / 2)$ of $100.0 \mathrm{~m},(M N / 2)$ of $15.0 \mathrm{~m}$. Using the conventional partial curve matching technique with two-layer master curves in conjunction with auxiliary point diagrams
(Orellana and Mooney 1966), the initial estimates of VES data was achieved. From this, estimates of layer resistivities and thicknesses were obtained, which served as starting points for computer-assisted interpretation. The conventional curves and auxiliary point diagrams (theoretical curves) used in the interpretation helped in obtaining a good fit between the observed field curves and the theoretical curves during total and partial matching. The computer software program WinResist was used and the datasets obtained from the manual interpretation stage were keyed as inputs into the computer modelling software (WinResist) to generate data for the estimated model. Figures 5-8 show examples of modelled VES curves obtained within the study area. From the interpreted data, it was possible to compute for every VES station the longitudinal conductance using equation (3) (Zohdy et al. 1974):

$$
S=\sum_{i=1}^{n} \frac{h_{i}}{\rho_{i}}
$$

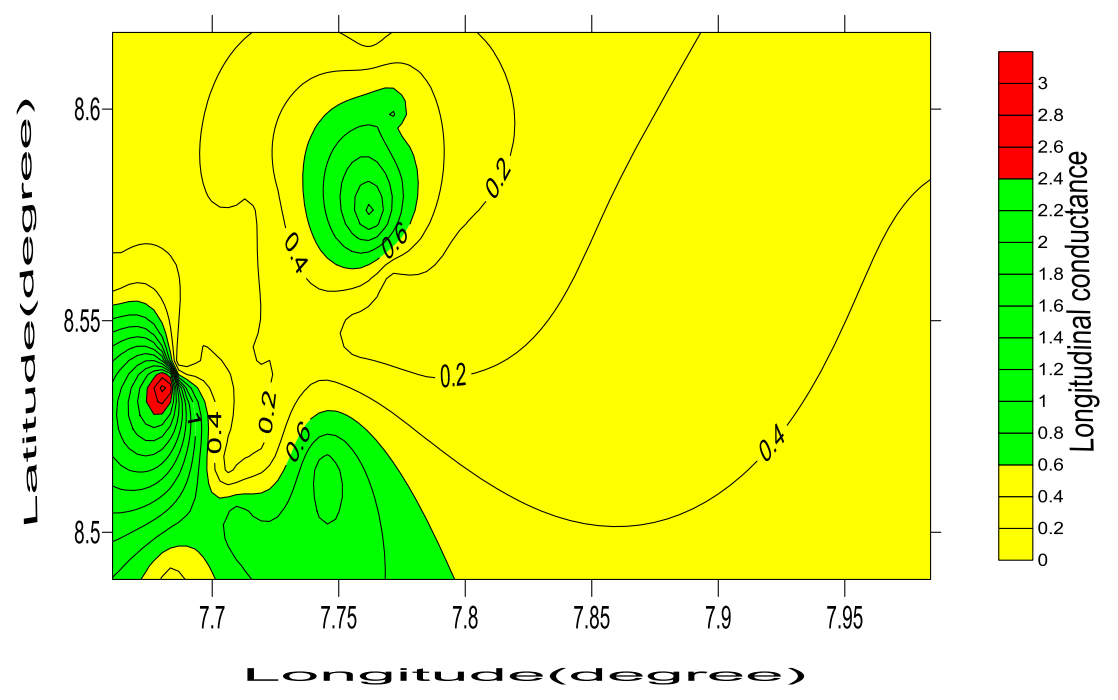

(a)

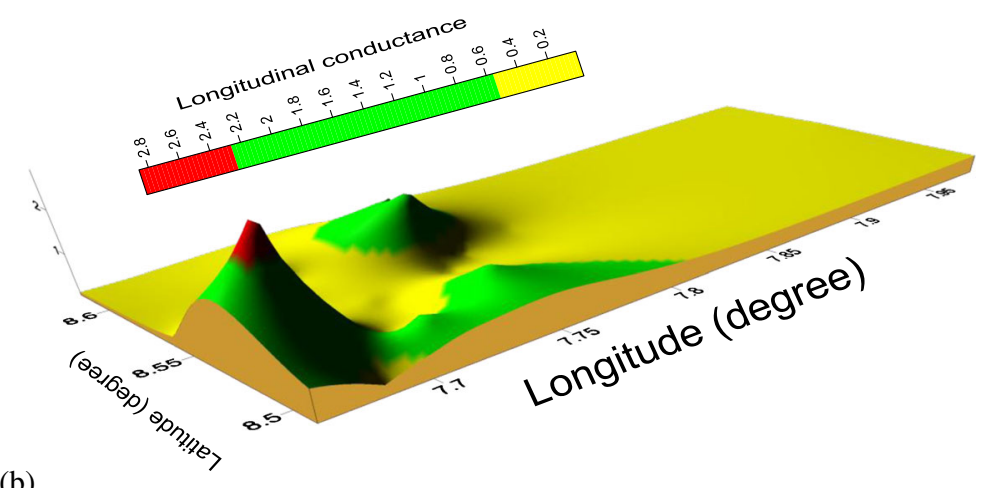

(b)

Figure 10. (a) Map of distribution of longitudinal conductance. (b) 3D distribution map of the longitudinal conductance of the study area. 
where $h_{i}$ is the saturated thickness of each layer, $\rho_{i}$ is the true resistivity of each layer. Soil corrosivity was evaluated using the resistivity value of the first layer on each VES point in the study area by comparing with the corrosivity rating (table 3 ).

\section{Results and discussion}

The information obtained from geophysical investigation (table 1) reveals that the study area geoelectric parameter shows three to four geoelectric layers with different curve types across the research area, and was characterized by varying resistivity values. The thickness of the topsoil ranges between 1.0 and $5.0 \mathrm{~m}$ and the layer resistivity varies from 5.0 to $1659 \Omega \mathrm{m}$. The partially/weathered layer thickness ranges from 1.0 to $63.7 \mathrm{~m}$ with resistivity varying from 10.0 to $1276 \Omega \mathrm{m}$, indicating that the material composition is largely clay, laterite, sandy clay, and clayey sand. The partially/ fractured sandstone resistivity values range between 109.0 and $800.0 \Omega \mathrm{m}$ which indicate high degree of fracture and/or water saturation. It is of infinite thickness where it is the last observable layer. Thirty VES points, which cut across the study area were selected and used to evaluate the protective capacity of the aquifer in the study area. The curves were grouped into 10 types as $16.67 \%$ of $\mathrm{QH}, 30 \%$ of $\mathrm{KQ}, 6.67 \%$ of $\mathrm{AA}$ and $\mathrm{K}$, $3.33 \%$ of $\mathrm{HA}, \mathrm{Q}$ and $\mathrm{A}, 10 \%$ of $\mathrm{H}, \mathrm{KH}$ and $\mathrm{HK}$. The dominant curve type is KQ with $30 \%$ each. The frequency distribution of the curve types is shown in figure 9 .

Using the inferred layer resistivities and thicknesses, longitudinal conductance (a Dar Zarrouk parameter) was used as a criterion for the aquifer protective capacity rating according to the rating

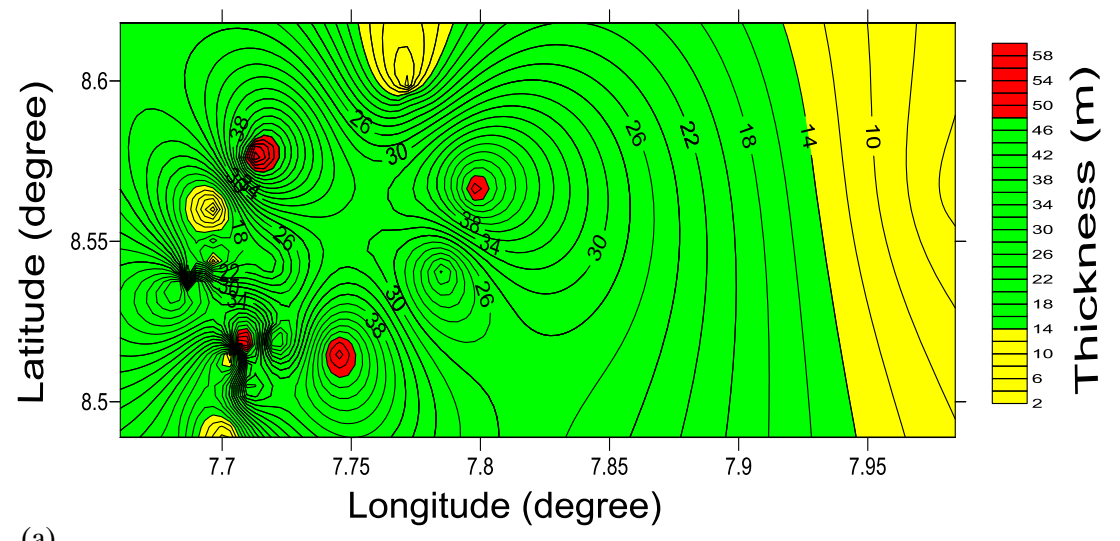

(a)

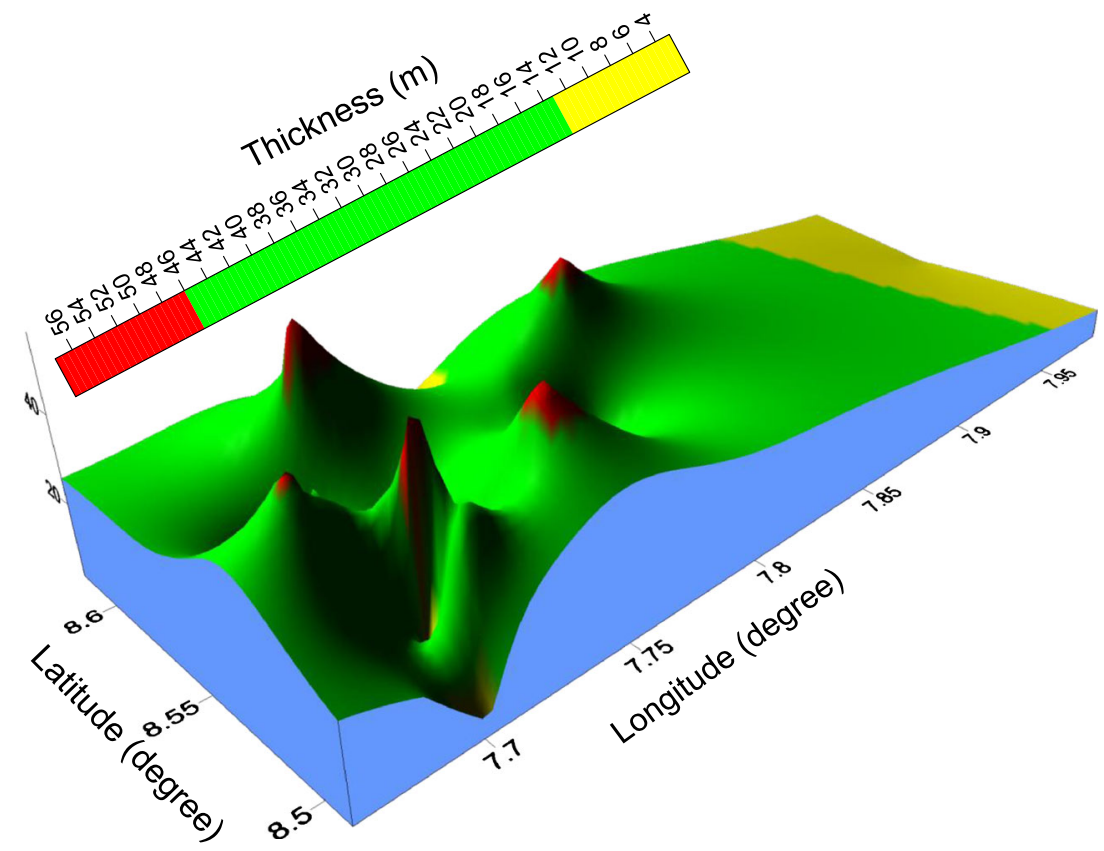

(b)

Figure 11. (a) 2D distribution of aquifer thickness in the study area and (b) 3D map showing the distribution of aquifer thickness in the study area. 
in table 2. The four distinct zones defined are weak, poor, moderate, and good aquifer protective capacity, based on the numerical values assigned to each point. VES 1, 4, 6, 7, 8, 9, 10, 12, 14, 19 and 28 have weak aquifer protective capacity covering $36.67 \%$ of the mapped area. $10 \%$ poor protective capacity was obtained in VES 3, 17, and 25; $40 \%$ moderate protective capacity in VES $2,5,11,15,16,18$, $20,22,24$ and $26 ; 13.33 \%$ good aquifer protective capacity in VES 13, 21, 23, and 27.

The earth's medium acts as a natural filter to percolating fluid. The ability of the earth to retard or accelerate and filter percolating fluid is a measure of its protective capacity (Barker et al. 2001) Figure 10(a and b) shows the distribution of longitudinal conductance in the study area.

The poor and weak zones are zones which are vulnerable to surface contaminant materials, which have less protective capacity. The study also revealed that areas with aquifer protective capacity ranging from moderate to good coincide with zones of appreciable overburden thickness with clayey columns, which are thick enough to protect the aquifer in the area from surface polluting fluid. A 2D and 3D thickness map of the aquiferous layer (figure 11a and b) shows that the aquifer thickness is highly variable in the study

Table 3. Classification of soil resistivity in terms of corrosivity (Baeckmann and Schwenk 1975; Agunloye 1984; Oladapo et al. 2004).

\begin{tabular}{ll}
\hline Soil resistivity $(\Omega-\mathrm{m})$ & \multicolumn{1}{c}{ Soil corrosivity } \\
\hline$<10$ & Very strongly corrosive (VSC) \\
$10-60$ & Moderately corrosive (MC) \\
$60-180$ & Slightly corrosive (SC) \\
$\geq 180$ & Practically noncorrosive (PNC) \\
\hline
\end{tabular}

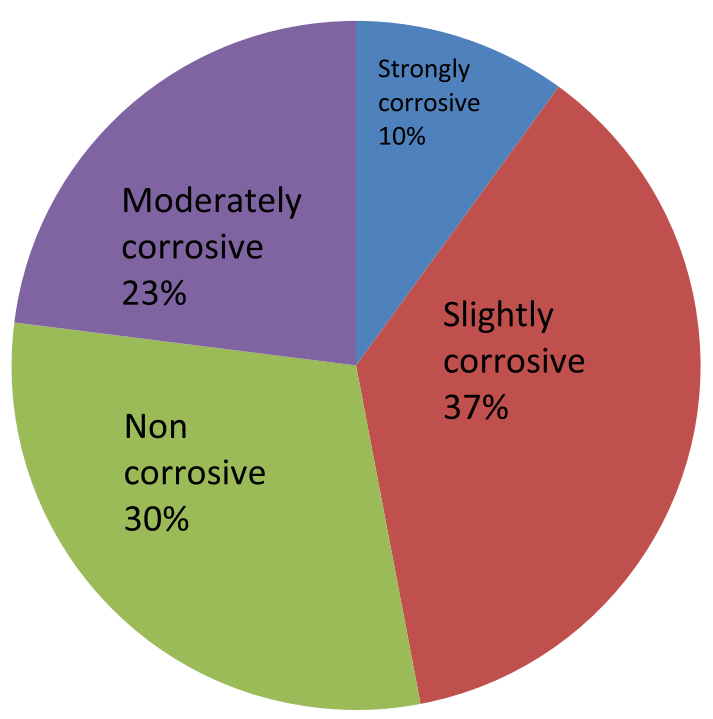

Figure 12. Soil corrosivity rating of study area. area. From the vertical and lateral extents of the map, it is seen that the thickness in the eastern part of the study area is thinnest in a continuum. The maps and table serve as guides to the locations of aquifers, aquifers protective capacity, and their distributions throughout the entire study area.

The result from pumping tests shows that the study area has static water level (SWL) of $4.68 \mathrm{~m}$, maximum draw down of $32.32 \mathrm{~m}$, average draw down of $1.47 \mathrm{~m}$, dynamic water level (DWL) of $37.0 \mathrm{~m}$, average pumping rate of $0.82 \mathrm{I} / \mathrm{s}$ and transmissivity $(T)$ as $1.30 \mathrm{~m} /$ day.

The soil corrosivity in the study area was also determined from table 1, using the first layer resistivity and comparing with that of table 3 . VES $1,2,10,17,18,20,23,27$ and 28 suggest that the subsurface (soil) is practically noncorrosive. VES $3,5,9,11,13,14,22,24,25,26$, and 29 indicate slightly corrosive material. VES 4, 6, 7, 8, 12, 16, and 19 suggest moderately corrosive material. VES 15,21 , and 30 indicate strongly corrosive material. Figure 12 shows the corrosivity rating of the study area.

\section{Conclusion}

The electrical resistivity (Vertical Electrical Sounding) method is an efficient tool for most groundwater studies. It was used in this study to investigate the protective capacity and corrosivity of overburden units in the study area. The frequency of the curve types indicates regular presence of $\mathrm{K}$ and $\mathrm{H}$ curves. This indicates the translation of layers with limited hydrologic significance into prolific units in which the selection of the best near surface and economic groundwater aquifer repository is, based on aquifer thickness and its degree of exposure to surface contaminants. Areas of thick overburden units and low resistivity values constitute zones of high longitudinal conductance. Regions with poor protective capacity (Shamija Village and New G.R.A.) are vulnerable to pollution and contamination if there is oil spillage, leakage in buried storage tank, petroleum pipelines, and infiltration of leachate from decomposed dump or waste site. Regions of weak protective capacity (Judges Quarters, Owners Occupier, Nyiman Layout, High level, Mission ward, Lafia road, 72 Battalon barracks, Uchonu village, and Wurukum) are less vulnerable to groundwater pollutant or contaminant but can be more vulnerable with time as pollutant persists. Moderate protective capacity regions (Industrial estate, CAPS Staff Quarters, INEC Office, Naval School, Naka Road, Lower Benue Staff Quarters and Kanshio) and good protective capacity (UniAgric road, Wadata, Ankpa Quarters) will forever serve as a sealing potential 
for the underlying hydrologeological system. This makes the contamination of groundwater in such regions almost impossible. Laboratory checks can be conducted from time to time in order to access the protective capacity of aquifers within regions described as poor and weak. Areas that are very strongly corrosive (CAPS Staff Quarters, Wadata and Kanshio) and moderately corrosive (Owner Occupier, Nyiman layout, High level, Lafia road and Uchonu village) are characterized by low resistivity values and high moisture content of the soil. Underground iron storage tanks are not to be buried in these areas. Reticulation of water, transmission of oil and gas using galvanized pipes could deteriorate, rupture or leak due to the reactions of corrosive materials with buried pipes, which can cause serious hazards to mankind and its environment. Plastic pipes are more preferable in these areas. In slightly corrosive areas (Industrial estate, Naval School, New G.R.A, Naka Road, Lower Benue Staff Quarters), concrete underground reservoirs can be constructed for water storage and steel pipes could be used for piling oil and gas. Practically noncorrosive areas (Judges Quarters, Mission ward, UniAgric road, 72 Battalion barrack, Shamija village, Mission ward, Ankpa Quarters, and Wurukum) are absolutely good for burying of iron underground tanks without deterioration.

\section{Acknowledgements}

Authors are grateful to Mr Victor Omonona, Dr J U Chukudebelu and Prof. F N Okeke (FAAS) for their wonderful contributions. They thank Subimal Ghosh, the Associate Editor and the reviewers for their meticulous fast review work.

\section{References}

Abiola O, Enikanselu P A and Oladapo M I 2009 Groundwater potential and aquifer protective capacity of overburden units in Ado-Ekiti, southwestern Nigeria; Int. J. Phys. Sci. 4(3) 120-132.

Adeniji A E, Omonona O V, Obiora D N and Chukudebelu J U 2014 Evaluation of soil corrosivity and aquifer protective capacity using geo-electrical investigation in Bwari basement area; Abuja. J. Earth Syst. Sci. 123(3) 491-502.

Agunloye O 1984 Soil aggressivity along steel pipeline route at Ajaokuta, southwestern Nigeria; J. Mining Geol. 21 97-101.

Amadi A N, Ameh M I and Jisa J 2010 The impact of dumpsites on groundwater quality in Makurdi Meteropolis, Benue State; Nat. Appl. Sci. J. 11(1) 90-102.

Baeckmann W V and Schwenk W 1975 Handbook of cathodic protection: The theory and practice of electrochemical corrosion protection technique; Cambridge Press.
Barker R, Rao T V and Thangarajan M 2001 Delineation of contaminant zone through electrical imaging technique; Curr. Sci. 81(3) 277-283.

Benue State Water Supply and Sanitation Agency 2008 Unpublised Report.

British Geological Survey 2001 Sketch map of the geology of Benue State; Report on visit to a Water Aid project, Nigeria, to carry out workshops and assess geology of Benue State; Keyworth, Nottingham.

Chernicoff A E and Whitney I K 2009 An introduction to physical planning; Houghton Mifflin Company, New York.

Dahlin T 2001 The development of DC resistivity imaging techniques; Comput. Geosci. 27(9) 1019-1029.

Dan-Hassan M A 2001 Determination of geo-electric sequences and aquifer units in part of the basement complex of north-central Nigeria; Water Resour. J. Nig. Asssoc. Hydrogeol. 12 45-49.

Edet A and Worden R H 2009 Monitoring of the physical parameters and evaluation of the chemical composition of river and groundwater in Calabar (southeastern Nigeria); Environ. Monit. Assess 213(1-3) 243-258.

George N J, Nathaniel E U and Etuk S E 2014 Assessment of economical accessible groundwater reserve and its protective capacity in eastern Obolo local government area of Akwa Ibom State, Nigeria, using electrical resistivity method; Int. J. Geophys. 7(3) 693-700.

Henriet J P 1976 Direct application of Dar Zarrouk parameters in groundwater survey; Geophys. Prospect. 24 344-353.

Ibuot J C, Akpabio G T and George N J 2013 A survey of the repository of groundwater potential and distribution using geoelectrical resistivity method in Itu local government area (L.G.A), Akwa Ibom State, southern Nigeria; Cent. Eur. J. Geosci. 5(4) 538-547.

Kalinski K J, Kelly W E and Bogardi I 1993 Combined use of geoelectric sounding and profiling to quantify aquifer protection properties; Groundwater 31(4) 538544.

Keswick B H, Wang D and Gerba C P 1982 The use of micro-organisms as groundwater tracers - A review; Groundwater 20(2) 142-149.

Kogbe A C 1989 Geology of Nigeria; Elizabethan Publishing Company, Lagos, Nigeria.

Makeig K S 1982 National buffers for sludge leachate stabilization of groundwater; Geophysics 20(4) 420429.

Mogaji K A, Adiat K A N and Oladapo M I 2007 Geoelectric investigation of the Dape Phase III Housing Estate F.C.T Abuja, north-central Nigeria; J. Earth Sci. 1(2) 76-84.

Offodile M E 1976 A review of the geology of the cretaceous of the Benue Valley; In: Geology of Nigeria (ed.) Kogbe C A, Elezabethan Publishing Company, Lagos, Nigeria, pp. $319-330$.

Offodile M E 2002 Groundwater study and development in Nigeria; Mecon Services Ltd., Jos, Nigeria.

Oladapo M I, Mohammed M Z, Adeoye O O and Adetola O O 2004 Geoelectric investigation of the Ondo State Housing Corperation Estate; Ijapo, Akure, southwestern Nigeria; J. Mining Geol. 40(1) 41-48.

Omoyoloye N A, Oladapo M I and Adeoye O O 2008 Engineering geophysical study of Adagbakuja Newtown development, southwestern Nigeria; J. Earth Sci. 2(2) 55-63.

Orellana E and Mooney H 1966 Master tables and curves for VES over layered structures; Interciencia, Madrid, Spain.

Strahler A N 1973 Introduction to physical geography, 3rd; John Wiley and Sons, New York. 
Ugbaja A N and Edet M O 2004 Groundwater pollution near shallow waste dumps in Southern Calabar, Nigeria; Global J. Sci. 2(2) 199-206.

Yahaya N, Mat Din M, Noor M and Husna S 2009 Prediction of $\mathrm{CO}_{2}$ corrosion growth in submarine pipelines; Malaysian J. Civil Eng. 21(1) 69-81.
Zohdy A A R 1969 The use of Schlumberger and equatorial soundings in groundwater investigations near El Paso, Texas; Geophysics 34 713-728.

Zohdy A A R, Eaton G P and Mabey D R 1974 Application of surface geophysics to groundwater investigations; United State Geophysical Survey, Washington.

MS received 20 August 2014; revised 11 September 2014; accepted 12 September 2014 